Rupkatha Journal on Interdisciplinary Studies in Humanities (ISSN 0975-2935), Vol. 10, No. 1, 2018 Special Issue on "Interrogating Cultural Translation: Literature and Fine Arts in Translation and Adaptation" In collaboration with the Department of English, Amrita Vishwa Vidyapeetham Guest-edited by Dr. Hari M G, Amrita Vishwa Vidyapeetham, Coimbatore, India

DOI: https://dx.doi.org/10.21659/rupkatha.v10n1.08

Full Text: http://rupkatha.com/V10/n1/v10n108.pdf

\title{
Translating the Traveled Culture: an Analysis of Tamarind City: Where Modern India Began by Bishwanath Ghosh
}

\author{
Arpana Venu \\ Department of English, Amrita Vishwa Vidyapeetham, Amrita University, Coimbatore. \\ Email:venu.arpana@gmail.com.
}

Received September 27, 2017; Revised December 11, 2017; Accepted December 30, 2017; Published February 04, 2018.

\begin{abstract}
Travel writing, often reflects the culture of the traveled land through the cultural lens of the traveler. This article attempts to analyze how cultural translation operates in a travelogue. The analysis is based on Bishwanth Ghosh's Tamarind City: Where Modern India Began, an account of his experience as an outsider in the city of Madras. One of the primary reasons for selecting this particular text is that not many authors have extensively written about Madras (Chennai), one of the oldest cities of India. The travelogue unlike others that are mostly records of passing travels is different in a way that it documents the transformation of a city on account of the author's stay there for almost a decade. The well acclaimed travel critic Mary Campell has elaborated on the major concerns of the traveler, while encountering a foreign culture. . It therefore represents not only the changing times, but also the intra-cultural transformations along with the socio-political and demographic changes, that happened in a city with a long history.
\end{abstract}

Keywords: Cultural translation, travelogue, Madras city.

"There is no foreign land; it is only the traveler that is foreign" -Robert Louis Stevenson

Travel writing has grown as an interesting field of literary studies in the recent times. Even though it appeals to researchers in the field of anthropology, cultural studies and literary studies, the genre itself, as put forward by the travel critic Mary Baine Campbell(2002), is a kind of writing that:

provokes certain kinds of essential literary questions and formulations. Most interesting here are works of literary criticism that find themselves directly facing issues of power, knowledge, and identity as a consequence of the very nature of the formal matters raised. Formal issues that have been fully explored with relation to travel writing in recent decades include the nature and function of the stereotype, lexical matters such as the hidden etymologies,...the subjective presence of the author(s) in texts of knowledge, truth value in narrative writing, the independent or hard -wired shape of narrative itself, the rhetorical nature of 'fact', 'identification' in reading (with its consequences in social and political life), the representation of time, inter-cultural 'translation' and the function of metaphor and other figures.(p.263).

(C) Authors. Published by AesthetixMS under a Creative Commons Attribution Non-Commercial 4.0 International License (http://creativecommons.org/licenses/by-nc/4.0/). 
Cultural translation is a process that involves a transfer of culture. In order to understand cultural translation, it is necessary to familiarize with the term 'culture'. Although there is no perfect definition for the term, according to John Storey, culture refers to the "shared meanings we make and encounter in our everyday lives...the practices and processes of making meanings with and from the 'texts' we encounter in our everyday lives"(p.221). The acclaimed theorist, Raymond Williams defines culture as ordinary and as a way of life. He gives three different definitions of culture, the lived culture, the recorded culture, the period culture and culture of the selective tradition.

Cultural translation and culture studies go hand in hand. Cultural Studies is a critical field that seeks to find the ways by which culture functions in the modern world, cultural productions work and also the formation of cultural identities. However, the critic Chris Barker is of the view that cultural studies as a domain explores the production and inculcation of culture and that cultural studies constitutes the game of language in it. (Barker.2012)

From the above, it can be inferred that cultural translation refers not only to the linguistic translation from one text to the other, but also a transfer of ideas from one culture to another. Homi K.Bhabha(1994), in his well acclaimed book, The Location of Culture explains the function of cultural translation -"Cultural translation desacralizes the transparent assumptions of cultural supremacy, and in that very act, demands a contextual specificity, a historical differentiation within minority positions" . (p.327)

Travel writing is one of the interesting medium to translate culture, as the writer travels, makes observations and translates the observations based on real experiences verbally through the travelogue. The firmament of travel writing has gained popularity and wide acceptance over time .The importance of travel writing as a genre is asserted by the critic Roy Bridges(2002) as follows:

Travel writing...has a complex relationship with the situations in which it arose. It is taken to mean a discourse designed to describe and interpret for its readers a geographical area together with its natural attributes and its human society and culture. Travel writing may embrace approaches ranging from an exposition of the results of scientific exploration claiming to be objective and value-free to the frankly subjective description of the impact of an area and its people on the writer's sensibilities. (p.53)

To experience the culture of a particular land and to document the same is the prime objective of a travelogue. The traveler uses the work as a mouthpiece to take the readers to new destinations and exposes the culture of that place in a detailed manner through vivid descriptions. The writer facilitates the understanding of the reader who is unfamiliar with the locale, people and their culture, portrayed in the travelogue. By the term culture, the scholar means "the way of life or the ordinary life" (p.54) as given by Raymond Williams.

Travelogues serve as a bridge between two cultural identities and hence it would be interesting and thought provoking to take up a travelogue and interrogate the various problems in translating cultural nuances of the traveled city. The proposed study is analytic in nature and the Indian travelogue, Tamarind City Where Modern India is taken up for a close scrutiny. It is an account of the author, Biswanath Ghosh's life in Chennai (Madras) and his various observations about the life and culture of the people living there. It is interesting to note Boris Buden's(2006) view on Cultural translation. He is of the opinion that "the purpose of translation is not to facilitate the communication between two different languages and cultures, but to build one's own language..." (Buden 2006) 
Bishwanath Ghosh is an acclaimed Indian travel writer and journalist. He has published three travelogues to his credit- Chai Chai: Travels in Places Where You Stop But Never Get Off (2009), Tamarind City: Where Modern India Began (2012) and Longing, Belonging: An Outsider at Home in Calcutta(2014). The travelogue Tamarind City is an account of the writer's observations on Chennai, the place that has become his second home. It is a result of Ghosh's colossal efforts and keen observations in understanding a new city that has an array of cultural differences with that of the place where he had lived all the years till then. In a blog interview, when asked about the book on Madras, Ghosh responds by saying that eventhough Chennai was bornin 1640, earlier than any other cities in India, the ignorance about the city should be cleared and thus presented the city in the form of a travelogue.

It is a fact that much of the travel writers, both from East and West have shown not much interest in writing about the Southern part of India, when compared to that of the North. Ghosh in his author's note begins with a disclaimer, "This book, however, does not pretend to be an exhaustive or authoritative study of Chennai or Tamil culture. It is born purely out of my desire to understand a city I've called home for over a decade now" (N.p)

The author exposes the various facets of the life of people in Chennai. By presenting a mélange of history, geography, arts and culture of Madras, he documents their unique culture in an interesting manner in this travelogue. Culture is the very way of life and travel writing depicts a detailed study of the everyday life and practices of a group of people living in a certain habitat..

One of the major problems, when it comes to conceptualizing culture is the prejudiced notions about a particular place and the stereotypes associated with it. Bhabha(1994) in his work, The Location of Culture, defines a stereotype- "...the stereotype...is a form of knowledge and identification that vacillates between what is always 'in place', already known, and something that must be anxiously repeated" .(p.94-95)

A common drawback of much of the travelogues is its stereotypical and prejudiced assumptions and descriptions of a particular place, people by the travel writer. Many travelogues are written based on second hand experience of the author, and not even by visiting the place. For instance, most of the travel writers from the west visit India with their pre conceived notions and stereotypical images and they are often shocked after they experience the reality. This is clearly given by the Indian travel writer, Pankaj Mishra (1995)in his popular travelogue, Butter Chicken in Ludhiana: Travels in Small Town India. He quotes a Westerner's idea about the Indian city Benares-

I suppose the shock was greater because of that, [happening in Benares] and also because we had just come up from the South where we had faced absolutely no problems at all...I think it also has something to do with the present moment, with how people treat each other in daily life, civic manners, a certain basic decency towards women, older people, and if you take that criterion, Benares comes right at the bottom of all Indian cities we visited (p.211-12).

India is very much stereotyped since ages. India is either identified as a treasure house of spices and wealth or as a synonym of poverty and darkness. Donald F.Lach (1968) says that India was a synonym for wealth and also a land of dark-skinned natives, free from diseases and endowed with magical powers in the popular imagination.

India is a multi cultural, multi lingual country which has hundreds of ethnic groups holding on to practices that are unique in several ways. Due to cultural diversity, within the 
country itself, a lot of misconceptions and pre conceived notions that at times lead to stereotyping occurs in the minds of the people who resides there. In the prologue to the travelogue, Tamarind City Where Modern India Began, the travel writer, Bishwanath Ghosh(2012)brings out a stereotypical viewpoint of a fellow North Indian passenger in train on his way to Chennai-

“'Do you live in Chennai? I asked him. It had been hours since I had spoken to anyone.

He recoiled in mock horror at my question. Then, slapping his palms together, burst out laughing.

'Chennai main rehkar marna hai kya?' he asked. 'Do you think I'm crazy to be living in a place like Chennai?'

His body was still shaking with mirth ". (p.xiii)

Due to the stereotypical notions, all South Indians are considered as Madrasis by the North Indians, just like how Americans regard Indians as people who smell of curry. The author(2012), in his prologue clearly brings out-

The lay north Indian has known very little about Chennai except that it is inhabited by conservative and religious people called Madrasis who live on idli and dosa. There was no need to know more. The south, for the north, was always the back of beyond. People from the south came to the north in large numbers to work. But there was no movement in the reverse direction...(p.xxv)

India is unique in the sense that there is an amalgamation of diverse traditions and cultural practices resulting in every state having its own identity. This, at times leads to misinterpretations and even apathy amidst the general populace.

Bishwanath Ghosh, to a certain extent, has overcome the North Indian stereotyped view in writing about a city in South India. Ghosh lives in Chennai, spends enough time in understanding the people, by taking efforts in identifying the history of the city and the factors that brought changes in the city; and also introduces the readers to the peculiar culture of the city. However, a South Indian reader can easily figure out his stereotypical notions about the Tamil culture and the ways by which he has looked down upon the people in this travelogue.

"Even today, it is common to see Brahmin men, no matter where they work or what positions they hold, wearing the caste mark on their foreheads-the general exceptions being those who have had a liberal upbringing outside Tamil Nadu or have grown up in anglicized homes"(Ghosh 61). Here, the travel writer has conveyed a wrong idea about Tamilians. Wearing a caste mark on foreheads is not something to be identified solely with the Brahmin men. It is not limited to one particular caste alone. Wearing such marks on forehead, in the present time has become a matter of personal choice among the people. Certain people wear it on their foreheads, while certain others may not. It would have been better, if the writer had put it in a generalized manner rather than associating it with a particular caste alone.

The researcher analyses that the writer has his own filters in his mind being an outsider and by describing certain practices of Tamilians, Ghosh(2012) has tried to ridicule those practices rather than merely presenting them as factual information to the readers. For example, he creates a visual image of a Tamil girl going to gym as follows-

There is a plump woman I run into every afternoon...On the treadmill, she walks like a toddler practicing her first steps. The jasmine retains its freshness, she her weight...Apart 
from me, no one, not even her trainer, seems to find her attire or attitude out of place. (p. $59-60)$

The last sentence needs to be considered. The author is disturbed by the very visual of a Tamil lady dressed in a traditional way. In another context, he makes fun of an old Brahmin lady whom he meets during a musical festival at Parthasarathy temple. He quotes- "I am Mrs.Parthasarathy', she replies. The name suits the setting. That's not even her name, but her husband's. It's the name she wants society to know her by". (p.265) The author sounds a little crude in his remark. As an Indian, he must have known that throughout India, the practice of using husband's name is the result of a colonial hangover. To extend it further, in the rest of India, woman takes up the caste name of her husband, thereby being addressed as 'Mrs.Gupta', 'Mrs.Sharma', etc.

Most of the travelogues are carriers of culture and the act of cultural translation is involved while documenting the socio-historical and cultural aspects of a particular habitat. A major hindrance that arises in the course of cultural translation, while conceptualizing culture is the element of subjectivity of the author, one of the striking features of a travelogue. A major part of the travelogue consists of the writer's observations and personal experiences during the span of travel in a particular country and the element of subjectivity is inevitable unless the author intends to write it the other way.

"If all travel involves an encounter between self and other that is brought about by movement through space, all travel writing is at some level a record or product of this encounter, and of the negotiation between similarity and difference that is entailed". (Thompson.p. 10) This observation by the travel critic Carl Thompson(2011) makes it clear that subjectivity is an inevitable part of any travelogue. In general, travel writers depict various social, political, cultural and geographical aspects of a place they visit and explore. In this effort, the author brings his/her views of a traveled land and tries to familiarize the readers with the new culture. The subjectivity may lead the author to disregard certain things in the new place while the writer may at times often elaborate too much on an area that interested him/her during the travel, without even considering if it may get monotonous or make the readers feel bored.The travel narrative in such cases become more of a diary writing, where the writer observes everything and jots them in a very personal manner.

For instance, Ghosh's personal liking for the children's magazine Chandamama and his childhood fascination for the artist Sankar who drew the pictures for the popular 'Tales of King Vikram and Vetala' series (196) has made him devote a whole chapter in this travelogue namely 'Chandamama and Madras Miscellany'. The writer takes his readers to his childhood days, the various factors that led him to take a liking for the magazine and elaborates on the effort he took in finding the artist Sankar and finally presents the conversations he had with his favorite artist. He describes Sankar-

But there is one employee of Chandamama who has remained immune to change. His life remains just the way it was in $\mathbf{1 9 5 2}$, when he joined the magazine as an artist. Today, Sankar is eighty-seven but he continues to draw pictures depicting the timeless era of the gods and the goddesses, the kings and the queens...for some inexplicable reason, I had always imagined Sankar to be tall, dark, lean, shy and withdrawn. But the Sankar I am meeting now turns out to be good-natured and garrulous in a very childlike way-he is very much the brand ambassador of the innocent era he portrays in his sketches. (p.203-04)

Ghosh then presents the biography of Sankar in a detailed manner. He begins, "Sankar, or K.C. Sivasankaran, was born in 1924 in a village called Karatholuvu near Coimbatore. His father was a 
teacher in the local school..." (p.205) Here, Bishwanath Ghosh is likely to have forgotten his primary task as a travel writer and has deviated from his main theme. This can be seen as a result of subjectivity of the author.

Bishwanath Ghosh, in his travelogue shows much interest in documenting the history of Madras city and the way by which the city underwent various changes over time.

Even First Line Beach, the most vital road of Madras in the early colonial era, with the harbor on one side and the all-important public buildings on the other, appears deserted in 1910 photograph. As if it is under curfew. Today the same road, renamed Rajaji Salai, is as much a nightmare for the motorist as the pedestrian. If any place in the city remains as unpopulated as it was a century ago, it is perhaps the sea. (p.25-26)

"Translation is a kind of activity which inevitably involves at least two languages and two cultural traditions" (Toury 200). In the context of the travelogue taken for study, it is commendable that Ghosh attempts to understand the culture of Chennai and tries to translate the same to the readers by identifying certain elements that make the city different from other cities.

Bishwanath Ghosh also compares certain cultural aspects of the city with that of his own land. However, he himself reveals the chances of inappropriateness in the comparison made. His observation is brought out in the following paragraph :

The music season in Chennai is lot like Durga Puja in Kolkata, though far less boisterous and held on a much smaller scale. But the similarities are striking. The rasikas, or the lovers of music, like to sabha-hop, just like Bengalis pandal-hop. It is also during the music season that the traditional Tamil Brahmin, not very adventurous when it comes to food, loves to eatin the sabha canteen, just as the Bengali loves to eat at the stalls in various puja pandals...And of course, the sarees worn are expensive. Both events are crucial to the culture of their people and an assertion of their identities. A Tamil Brahmin girl who has never been to a music class is as good as a Bengali girl who has never seen a puja pandal. The comparison may not be entirely appropriate, but not entirely inappropriate either .(p.263.)

In another instance, the author gets fascinated by identifying something new in the already known culture.

...I hear the Hanuman Chaalisa playing in one of the nearby shops. Now, I've grown up in Kanpur listening to the Hanuman Chaalisa, live as well as in the recorded form, but never before had I heard a woman sing it, that too in a voice so powerful and persuasive that I slip my sandals back on and walk into the shop. I ask the shopkeeper to show me the CD he is playing. The singer turns out to be M.S.Subbulakshmi. (p.127.)

Another obstacle involved in the process of cultural translation is the language barrier. The language constraints may often stop the travel writer from understanding the cultural traditions in a foreign land. Linguistic constraints make the writer fail in understanding a new culture that he/she comes across during the course of travel.

India has diversity in terms of languages too and due to this linguistic diversity, a nonTamil speaking person finds it difficult to understand the nuances of culture in Chennai. Bhabha(1994) says-

The 'language' metaphor raises the question of cultural difference and incommensurability, not the consensual, ethnocentric notion of the pluralistic existence 
of cultural diversity... It represents the temporality of cultural meaning as 'multiaccentual', 'discursively rearticulated'. It is a time of the cultural sign that unsettles the liberal ethic of tolerance and the pluralist framework of multiculturalism. Increasingly, the issue of cultural difference emerges at points of social crisis, and the questions of identity that it raises are agonistic; identity is claimed either from a position of marginality or in an attempt at gaining the centre: in both senses, ex-centric .(p.254.)

In his endeavour to explore the identity of the city, Ghosh ponders over the etymological details of the name of the city- between Chennapatnam and Madraspatnam.

About Madraspatnam, the most plausible theory is that the name derives from the wealthy Madeiros family that lived in the nearby Portuguese settlement of San Thome. Chennapatnam, on the other hand, is widely believed to have taken its name from Chennappa-the father of Darmala Venkatappa, the local governor of the Vijayanagar Empire who had granted the strip of land to Francis Day to build Fort St George. Venkatappa was supposedly keen that the new settlement be named after his father. (p.24.)

Notwithstanding the name of the city, he even tries to understand the poignancy of the traditional South-Indian musical art form. Ghosh thinks aloud-

So, what does the word 'Carnatic' mean?

No one seems to be very sure. History will tell you that a particular region in south India represented today pretty much by the map of present-day Tamil Nadu-was called the Carnatic. But why was it called so? According to Sriram, the word derives from karna (the ear) and ata(to haunt).

The travelogue unlike others that are mostly records of passing travels, is different in a way that it documents the transformation of a city on account of the author's stay there for almost a decade. It therefore represents not only the changing times, but also the intra-cultural transformations. In this context, Ghosh compares the city with other Indian metros and writes:

It's the marriage between tradition and transformation that makes Chennai unique. In a place like Delhi, you'll have to hunt for tradition. In Kolkata, you'll itch for transformation. Mumbai is only about transformation. It is Chennai alone that firmly holds its customs close to the chest, as if it were a box of priceless jewels handed down by ancestors, even as the city embraces change. (p. xxvii.)

To sum up, it is appropriate to state that travel writers record their expeditions for someone else to relive and recapitulate the moments that they have experienced. They depict the cultural diversities of a region in terms of language, food, politics and life of the people. It is essential for a travel writer to cross the cultural boundaries and allow one to enter the new culture by breaking every single barrier, thereby getting exposed to a new place and new culture altogether. In order to attain that, the writer must be free from prejudices and inhibitions about the place to be visited/ the travel destination.

Through a close examination involved in the study, the researcher has tried to understand the cultural aspects and the narrative strategies used by the author. By analyzing the formal issues as stated by Mary Campbell, the various problems in translating Ghosh's personal travel experience as inferred from the words of Mary Campbell that can be found through the study are - the prejudices and stereotypical notions about a place, subjectivity of the author/ and the 
language barriers that he had faced during the process of narration. Despite this, his journalistidentity has made it easy for Ghosh to interact with people and know more about the culture of Madras by means of eliciting first-hand information through casual conversations, observations and personal interviews.

\section{References}

Bhabha, H.K. (1994). The Location of Culture. London: Routledge.94-95.

Hulme, P, \& Youngs, T.(2002). The Cambridge Companion to Travel Writing. U.K: Cambridge University Press.53.

Campbell.Mary. (2002). The Cambridge Companion to Travel Writing. Hulme, Peter, and Tim Youngs (ed) .Cambridge: U.K., Cambridge University Press. 53.

Barker, C. (2004). The Sage Dictionary of Cultural Studies. London: Betascript Publication.

Culler, Jonathan D. (2011). Literary Theory: AVery Short Introduction. Oxford: Oxford University Press. 41.

Ghosh, Bishwanath. (2012). Tamarind City Where Modern India Began. Chennai:Tranquebar Press.

Greenblatt, Stephen. (1995). Critical Terms for Literary Study. C Lentricchia, Frank, and Thomas McLaughlin.(Ed.). Chicago: University of Chicago Press. 225.

Lach, Donald Frederick. (1968). Southeast Asia in the Eyes of Europe the Sixteenth Century. Chicago: University of Chicago Press.

Mishra, Pankaj. (1995) Butter Chicken in Ludhiana: Travels in Small Town India. New Delhi: Penguin. 211.

NPTEL.Understanding Cultural Studies Part 1.Mod-o1 Lec-01, 25/10/2012. <https://youtu.be/CPjcdIFERGk>

Storey, John. (2013). Cultural Theory and Popular Culture: A Reader. London: Routledge. Taylor \& Francis Group. 220-24.

Thompson, Carl. (2011). The Routledge Companion to Travel Writing. London: Routledge.210.

Toury G.(1978). The Translation Studies Reader. London: Routledge.

Williams, Raymond. (1987). Culture and Society: Coleridge to Orwell. London: Hogarth. 54. 